\title{
DOS MIRADAS HACIA EL PASADO: RÉOUIEM EN CASTILLA DEL ORO Y ASALTO AL PARAÍSO: CONQUISTA Y COLONIA, DESMITIFICACIONES DE LA HISTORIA DEL PODER
}

\author{
Two looks to the past: Réquiem en Castilla del Oro and Asalto al paraíso: \\ conquest and colony, demystifications of the History of power
}

\author{
Marlene Salazar Horr \\ Universidad de Costa Rica, Costa Rica \\ salazarhorr@gmail.com
}

Recibido: $29-08-2017$

Aprobado: 04-10-2017

\section{RESUMEN}

Marlene Salazar Horr es licenciada en Filología Española por la Universidad de Costa Rica, egresada de la Maestría Académica en Literatura Latinoamericana de la misma universidad. Es profesora de Comunicación y Lenguaje de la Sede del Atlántico de la Universidad de Costa Rica.
Este artículo es un análisis literario de las novelas Asalto al paraíso de Tatiana Lobo y Réquiem en Castilla del Oro de Julio Valle-Castillo. Su objetivo es abordar la construcción de la identidad a partir de los discursos de poder planteados por la Historia oficial y evidenciar cómo estos silencian las pequeñas historias fragmentadas que conforman el crisol identitario durante la conquista y la colonia. Se toma como base los fundamentos teóricos de la Nueva Novela Histórica y cómo esta abre espacios para entrever a esos marginados históricos que son los indígenas y los negros, pues en ambos textos aparecen estos grupos silenciados. Incluso, en Asalto al paraíso se abre el espacio para que Pabrú Presbere, figura de la historia nacional que ha sido marginada por la oficialidad, nos presente su versión de la historia. Ambos textos se constituyen en nuevos espacios, no solo para decir la Historia, sino para escribirla. Por lo cual, esta publicación responde a una investigación cualitativa, que desarrolla un análisis de contenido enfocado en el manejo de elementos de carácter teórico, discursivo y simbólico presentes en ambas novelas.

Palabras clave: identidad; pasado; desmitificación histórica; Asalto al paraíso; Réquiem en Castilla del Oro

\begin{abstract}
This article is a literary analysis of the novels Asalto al paraíso by Tatiana Lobo and Réquiem en Castilla del Oro by Julio Valle-Castillo. Its objective is to approach the construction of the identity from the power discourses raised by the official History and to show how they silence the small fragmented histories that make up the identity crucible during the conquest and the colony. It is based on the theoretical foundations of the New Historical Novel and how it opens spaces to glimpse those historical marginals that are indigenous and black, because in these texts appear these groups silenced. Even in Asalto al paraíso, the space is opened for Pabrú Presbere, a figure of national history who has been marginalized by the official, to present us his version of history. Both texts are constituted in new spaces, not only to say History, but to write it. Therefore, this
\end{abstract}


publication responds to a qualitative research, which develops a content analysis focused on the handling of theoretical, discursive and symbolic elements present in both novels.

Keywords: identity; past; historical demystification; Asalto al paraíso; Réquiem en Castilla del Oro

\section{Consideraciones preliminares}

La novela histórica ha sido la tendencia predominante en la literatura latinoamericana en las últimas décadas, pues la historia ha sido vista como una fuente para la creación literaria. Para el caso particular de Centroamérica, este tipo de novela ha tenido un gran auge ya que ha tomado una gran cantidad de temas relacionados con los procesos históricos, políticos y económicos de la región. Pero a su vez, se ha alejado del canon de la novela histórica tradicional para generar elementos particulares con los cuales Seymour Menton, en su texto La nueva novela histórica de la América Latina 1979-1992, ha planteado la existencia de una Nueva Novela Histórica. En esta sobresalen seis aspectos: la subordinación, en distintos grados, de la reproducción mimética de cierto periodo histórico a la presentación de algunas ideas filosóficas, la distorsión consciente de la historia mediante omisiones, exageraciones y anacronismos, la ficcionalización de personajes históricos, a diferencia de crear personajes ficticios, la metaficción o los comentarios del narrador sobre el proceso de creación, la intertextualidad, como ejemplo el palimpsesto y los conceptos bajtinianos de lo dialógico, lo carnavalesco, la parodia y la heteroglosia.

De igual forma, otros autores han añadido más rasgos considerados propios de la nueva novela histórica. Entre ellos, María Cristina Pons (1996), quien propone los siguientes: subjetividad, relatividad de la historiografía, rechazo de la verdad histórica, un cambio en los modos de representar, generar una escritura desde los márgenes, abandonar la dimensión mítica, entre otros.

A la luz de estos conceptos, se han producido lecturas que se dedican a crear grandes listados para clasificar la producción novelesca de Centroamérica, según esos parámetros específicos. Réquiem en Castilla del Oro, del nicaragüense Julio Valle Castillo y Asalto al paraíso, de la chileno-costarricense Tatiana Lobo no han sido la excepción.

Ambos textos han sido clasificados como Nueva Novela Histórica ya que cumplen con muchas de las características citadas anteriormente. Y se 
generan en un momento particular: la conmemoración de los 500 años del descubrimiento de América. Pues Asalto al paraíso es publicada en 1992 y Réquiem en Castilla del Oro en 1996. Ambas novelas desarrollan los temas del descubrimiento y la conquista desde diferentes perspectivas. Y ambas plantean un acercamiento a la Historia desde la historia.

Es importante recalcar que esta desmitificación cuestiona oficialidad de la historia nacional y su validez a la hora de armar ese constructo sociohistórico llamado identidad, pues en Costa Rica se ha silenciado por mucho tiempo el discurso desde la otredad indígena, y Asalto al paraíso se convierte en un incipiente acercamiento a ese otro indígena "Pabrú" que nos presta su mirada con el fin de desarticular la oficialidad histórica del discurso llamado Historia.

\section{Desapropiación de la Historia Oficial y recuperación de la voz}

El viraje significativo en ambas novelas es la desmitificación de la Historia Oficial, pues ambas se aventuran en un pasado colonial que crea las bases de la identidad nacional. En Asalto al paraíso Lobo "asalta" la historia oficial para desenmascarar los artilugios del poder en un doble juego (esta novela relata la rebelión indígena liderada por Pabrú Presbere).

Autores como Marco Vargas (1997), aseguran que el acontecimiento más importante de toda la obra es la sublevación indígena; sin embargo, este no ocupa el lugar central de la novela pues la narración gira alrededor de Pedro Albarán, un español fugitivo de la Santa Inquisición, quien se refugia en el Cartago colonial. A través de este personaje se presenta la vida colonial, llena de situaciones anómalas, denunciadas por una voz marginada, subalterna.

\footnotetext{
"Pedro había preparado un gran frasco de tinta y seis plumas resintiendo que toda la escritura debía hacerla en papel sin sellos, porque así se lo había exigido Granda.". (Lobo, 1998, p. 304).
}

Pedro, al ser escribiente, entra en contacto con el poder y sus manejos truculentos, que delatan abusos e infamias contra los indígenas y los negros esclavos. Y con este último aspecto se contradice la Historia Oficial, que plantea que en esta provincia no se trasegaba con esclavos. En Asalto al paraíso se presenta una focalización especial, pues Pedro Albarán, un marginado, es el encargado de mostrarnos los abusos del poder en contra de otro marginado: el indígena. La Historia se narra desde una marginalidad, desde abajo, tanto en la voz de Pedro como en la voz de Pabrú. 
Para el caso de Réquiem en Castilla del Oro se toma como eje central la figura histórica del conquistador Pedrarias Dávila. Este personaje se plantea como un antihéroe, igual que Albarán, pero con alcances devastadores. Si Pedro fue instrumento del poder, Pedrarias es el poder mismo, que se encarga de subyugar y destruir las voces que lo rodean.

\footnotetext{
"A la hora nona del martes, Pedrarias quiso mostrar su mando y medios y me sentó en el corral a presenciar el aperreamiento de dieciocho indios... Desde su tribuna, el gobernador presidió el suplicio. Sus mastines derribaron en el primer estante a los seis hombres, abalanzándoseles al pecho..." (ValleCastillo, 1999, p. 124).
}

Si bien esta voz oficial, la voz de Pedrarias, está presente a través de todo el texto; también, las voces de los marginados deambulan por la novela, denunciando los atropellos del poder.

\footnotetext{
"Vete al jardín de Al'lah, alférez moro de Orán (...) precipita por las escaleras el turbante primero y tu cadáver después". (Valle-Castillo: 1999: 200).

"-Si no tienes piedad de él, que es tu criado, que es tu siervo, ¿qué será de nosotros en Castilla del oro?

-Ten piedad Señor, de nosotros, dice el cacique Ponca y repite el cacique Comogre en Tierra Firme.

El esquilmado y robado y ultrajado cacique Pocorosa pide piedad.". (ValleCastillo, 1999, p. 201).
}

En ambos textos, aunque priva el abuso del poder, la violencia y la injusticia, se abre un espacio para esas voces marginadas, subalternas que cuentan la "historia" desde su propia voz, denuncian. En Réquiem en Castilla del Oro, todavía con más fuerza, a través de la palabra indígena.

\section{"Nican-atl-hua}

Nicalt-nahuac

Xicallihua, Nicaroguán, Nicaraguay, Nicaragua, Nec-arawak, Nicaragica: aquí existimos, existimos aquí junto al azul cambiante y el verde líquido/Nosotros, los señores de las aguas dulces y de las aguas saladas..." (Valle-Castillo, 1999, p. 49).

\section{La escritura performativa: torrentes de letras que buscan la Historia y su encuentro con las historias}

En ambas novelas, para recrear los hechos históricos, se recurre a un manejo particular del lenguaje, ya que los dos autores escriben desde el presente un acontecimiento del pasado. De esta manera, lo reescriben, lo reinventan con la voz del pasado que guardan los textos y los ojos del presente que deambulan por las letras. Así lo afirma Héctor Leyva (2005): 
"Escrita en un estilo neobarroco descendiente de la rancia estirpe del barroco hispánico y renovado por la rebeldía y el onirismo vanguardista canonizado en la narrativa del boom, la novela confía en el poder mitopoético de la palabra, en el hallazgo de la imagen que puede conjurar el tiempo e iluminarlo." (s.p.).

Las dos obras utilizan como base textos históricos que son alterados, modificados y cuyo efecto produce una gran verosimilitud, tal vez más que la misma Historia. Esto es evidente en el empleo del lenguaje, en las descripciones y en la estructura de los personajes históricos. Se transforma en un juego, pues el conocimiento histórico produce la escritura, y esta a su vez, cuestiona "la verdad" y produce su nueva verdad, su historia.

Estas letras transitan por gran cantidad de documentos históricos como los Archivos de la Curia Metropolitana y las Crónicas de la Conquista, pero en ese camino se enredan y se entrecruzan con diferentes discursos como el cultural, el político, el religioso, entre otros. Cada uno de ellos plantea críticas que atentan contra la memoria oficial. Como el siguiente fragmento de Asalto al paraíso que pone en entre dicho la función de la Iglesia.

"Pedro, al escuchar el chocochoco que hacía el molinillo de la cocina de la casa cural, creía ver, en la molienda, las almas de los fieles, trituradas, pulverizadas, disueltas en leche, y luego deglutidas por el comisario." (Lobo, 1998, p. 56).

En Asalto al paraíso la estructura de los títulos, además de presentar un resumen de los acontecimientos, evidencia un distanciamiento en la prosa presente. De igual forma el lenguaje poético puesto en la voz de los indígenas, ya que presenta el contraste entre ambas visiones de mundo.

"Las cosas verdaderas están en los mundos inferiores: de allá abajo nace la vida, allá abajo el hombre tiene su raíz; y también su cabeza, porque abajo regresamos al morir. Este es el misterio que los hombres de musgo en las quijadas no pueden comprender". (Lobo, 1998, p. 9).

En Réquiem en Castilla del Oro se utilizan verbos con pronombre enclítico y de esta manera se recrea el estilo de la época, con el fin de dar veracidad a la novela, según Isolda Rodríguez (2005). Como puede verse en este fragmento que relata el manejo de la situación política y la lucha por el poder efectuada por Pedrarias.

"Yo os traté bien en Panamá y para esta empresa de Nicaragua porque creía en vos, don hideputa bellaco, había la fidelidad que al rey y a mi en su nombre debías, pero os querías alzar contra la corona y por tanto os trataré como a enemigo, y os juzgaré como a traidor y ladrón probado,". (ValleCastillo, 1999, p. 103-104). 


\section{Los personajes históricos y el juego de las metáforas}

En ambas novelas los personajes históricos preponderantes funcionan como metáforas de una contrahistoria o una infrahistoria silenciada por la oficialidad, pues en ellos convergen la historia, la ideología y la ficción. Ese "esqueleto" histórico ha sido revestido por la mirada y el pensamiento de otro, quien juega y lo disfraza con ideas, textos, sueños y añoranzas.

En Asalto al paraíso es Pabrú Presbere, líder de la sublevación indígena en Talamanca quien condensa la figura del valor y la entereza de toda una raza, una raza de olvidados. Presbere es la imagen del guerrero que lucha contra la opresión y en él se representa la tragedia de su pueblo, ya que su muerte (arcabuceado) equivale al silenciamiento de los suyos.

\footnotetext{
"Era la segunda vez en toda su vida que Presbere sentía el terrible mordisco de la duda. Toda su tarea, la batalla contra los cristianos había obedecido a un plan perfecto, hasta los últimos detalles. Todos los ritos se habían cumplido; había sido extremadamente cuidadoso con los ayunos. Ahora las piedras estaban mudas. La caverna estaba muda. El Kapá también enmudecía". (Lobo, 1998, p. 234).
}

De igual manera, podría verse como la muerte de la lucha, ya que todos los demás indígenas se describen como andrajosos, esmirriados e indefensos, solo él es descrito con la fuerza y el porte del guerrero.

"Era un indio en la madurez de su vida. Estaba parado ahí con toda la dignidad que le permitían los calzones de manta andrajosa con los cuales había tapado la maciza musculatura de sus muslos". (Lobo, 1998, p. 305-306).

Pabrú sigue todo un proceso para enfrentar a sus enemigos; sin embargo, este plan es la preparación para el final inminente. De cierta forma, sigue todo un ritual que lo convertirá en el sacrificio de su raza, una suerte de figura crística que resucitará en los sueños de una raza marginada, silenciada y olvidada por el poder.

En Réquiem en Castilla del Oro la gran metáfora es Pedrarias Dávila, quien simboliza el abuso del poder y todos los males que esto conlleva: muerte, violencia, anulación, sufrimiento y dolor. Este es la simiente del poder que se perpetúa a través de toda la historia político-militar-social de Nicaragua y su figura condensa todos los gobiernos dictatoriales sufridos por el pueblo, inclusive, alude al gobierno sandinista. 
Este poder de Pedrarias se hiperboliza al construirlo como un gigante que sigue creciendo y aplastando al otro, al indefenso, al marginado. En él se condensa la imagen del tirano latinoamericano, y este se evidencia claramente en su inmortalidad, la tiranía instaurada en la colonia sigue aferrada al presente, sin que pueda preverse su fin.

\footnotetext{
"Otro ensayo de Juicio Final, pero un Juicio Final privado, particular, a domicilio, con el Juez Supremo e infalible sentado en su trono, haciendo patente todo lo oculto, desenterrando osamentas entre víboras y serpientes o cadáveres de carnes putrefactas, horadadas por su propia gusanera y amortajados de armaduras, coronas, mitras y ornamentos, abriendo el Libro Eterno y pasando las páginas donde están escritas cada una de las obras buenas y malas, pero dejando la sentencia postergada, sin condena ni absolución, para el día de la legítima muerte.". (Valle-Castillo, 1999, p. 35).
}

Es interesante el juego de intercambio de imágenes entre ambos personajes. Si bien, Presbere puede verse desde la historia oficial como "el demonio indígena" que mata sin piedad a los emisarios de Dios (Rebullida); los ojos no oficiales ven en él una figura crística que se sacrifica por la liberación de su pueblo y que sobrevivirá, mejor dicho, que resucitará en la tradición y la memoria de un pueblo que sueña con ser liberado de la opresión de un dios extraño.

"- Pedro- dijo-, ¿te has dado cuenta de que las lapas han volado hacia el oeste? Es porque acompañan al sol. El sol lleva el alma de Presbere prendida de sus rayos, hacia el mundo más abajo donde lo espera la inmortalidad". (Lobo, 1998; p. 314).

Sucede lo mismo con Pedrarias, ya que es construido por la historia oficial como el portavoz del poder divino. Él indica que sus actos son decididos y guiados por Dios, pues de Él proviene su poder y su misión es perpetuar ese poder de Dios en contra de la barbarie y el salvajismo de los indígenas. Pero para la contraparte indígena Pedrarias representa al "dios de los infiernos". Esta voz no oficial subvierte la imagen de Pedrarias de héroe de la conquista (Historia) a antihéroe de la historia.

"DAXCA-LU: Emisario de Dios, Anunciador de Dios. Todos los caminos de la tierra y el mar y los destinos llevan a, pasan por y convergen en PEDRARIAS, PEDRO, piedra angular y piedra de toque. PUERTO de salida y retorno PEDRARIAS FUROR DOMINE: él mismo, un señor furioso, la furia del Señor, la ira del Señor, señor de la ira, padre del fuego y de todo castigo, de toda peste y de todo mal: BISTEOT: COLOTL." (Valle-Castillo, 1999, pp. 88-89). 


\section{Escritura vrs oralidad: mecanismos de la ficción}

La escritura se constituye en el principal enemigo de la voz indígena, pues en ella se condensa la mirada y el discurso de los vencedores que desacredita todo aquello que esté fuera de su cultura. Tanto los indígenas como los negros son páginas arrancadas de esa historia, son un pasado perdido que solo puede recuperarse parcialmente en la oralidad. Así, las letras fundan la historia y la memoria de los pueblos.

En ambos textos juega un papel muy importante la figura del escribiente. En Asalto al paraíso, Pedro es la pluma que modifica la historia, pues su escritura es una voz de la conciencia que desmitifica el pasado consagrado por la Historia y crea una conflictividad con ese pasado. En esta escritura se ejerce un derecho a la memoria, una memoria no oficial que se instaura por medio de ese proceso de narración - escritura como creación ficcional. Pedro, en su carácter de personaje ficcional, funda las imágenes verosímiles del pasado que cuestionan ese olvido.

"Pedro ya se había acostumbrado a la composición variopinta de las indias occidentales, a la escala cromática de sus innumerables castas, a la revoltura que Europa, África y los aborígenes americanos habían procreado con resultados sorprendentes..."(Lobo, 1998, p. 15-16).

En Réquiem en Castilla del Oro, ocurre un fenómeno muy interesante, el autor, Julio Valle-Castillo se inserta como escribano real. De esta forma, se convierte en testimoniante de la historia y en una voz de autoridad en el texto. Juega con el pasado, lo dice y lo desdice, y la ironía se convierte en su mejor arma narrativa.

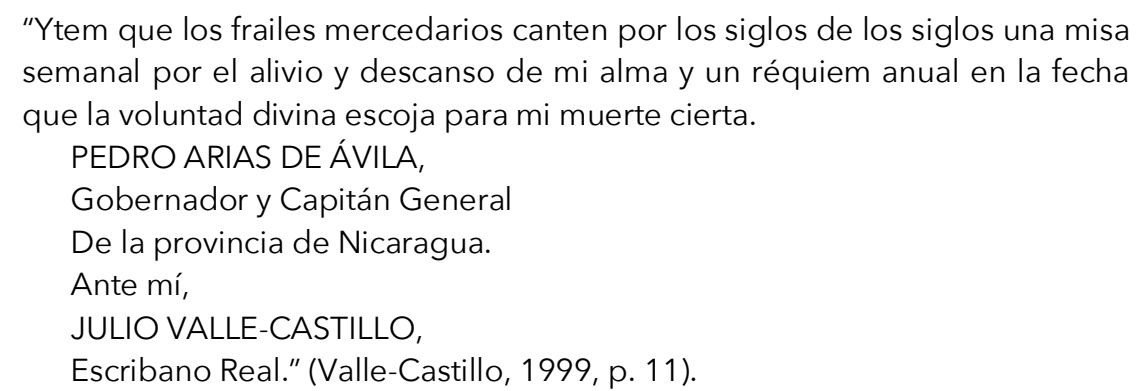




\section{Los juegos de la escritura: Palimpsestos, ironías e intertextos: entre la Historia y la ficción}

La escritura en su carácter dialogante y polifónico genera una reescritura o sobreescritura de la historia que se entrecruza con la ficción y utiliza una amplísima gama de mecanismos como lo son las omisiones, las exageraciones, los anacronismos y las parodias, entre otros.

Ambos textos juegan con estos mecanismos narrativos y presentan una $(\mathrm{H})$ istoria que se va armando ante nuestros ojos. Estas dos novelas tienen una macroestructura basada en las referencias a documentos históricos, pero de igual manera, los toman como pretexto para darle un entorno histórico a los documentos que produce la ficción. Para el caso de Asalto al paraíso, se evidencia en el último capítulo titulado: El Rey da las gracias, pues en él se toma la estructura de las cartas reales para producir un fragmento de la historia.

\footnotetext{
"con especialidad Teniente que enviasteis a la referida función, ha merecido de mi Soberana Grandeza el reconocimiento de su acertada conducta, por que le daréis gracias y a todos aquellos soldados y leales vasallos que concurrieron al castigo de los rebeldes y debida defensa de esa Provincia,... Fecha en Madrid, a primero de Septiembre de mil setecientos y trece. -YO EL REY-". (Lobo, 1998, p. 320).
}

De igual manera, en Réquiem en Castilla del Oro se encuentra el uso de palimpsestos como las crónicas de los conquistadores, si bien tiene como una de sus fuentes históricas las Crónicas de Gonzalo Fernández de Oviedo, también tiene textos como Brevísima y verdadera relación de Tierra Firme escrita por Vasco Núñez de Balboa, es un juego narrativo creado por el autor. Por lo tanto, este tratamiento de las fuentes y el juego que se produce con ellas muestran que la ficción adquiere un carácter de verosimilitud dentro del relato, como lo menciona Isolda Rodríguez (2005).

\footnotetext{
"Quiero certificarle, señor gobernador y capitán general Pedro Arias Ávila, que la relación de estos reinos que ayer me demandara en nombre de SM, irá desnuda de artificio, pero revestida de toda veracidad posible, de forma y manera que vuecencia pueda bien verificar los hechos, el estado, cosas, frutas y criaturas que aquí se expondrán". (Valle-Castillo, 1999, p. 236).
}

Un elemento presente en ambas novelas es el intertexto, pues por sus páginas se desliza una gran cantidad de textos que constituyen ecos del pasado y susurros del presente. En Asalto al paraíso se evidencia claramente como intertexto la cosmogonía indígena en la mención de Sibú-Surá. Este texto cultural refleja una realidad diferente a la europea, predominante en ese momento. 
"Ellos ordenaban el universo al revés, tienen un único Dios en el cielo, y no ven que Sibú es imposible sin Surá. Engañados por su dios solitario, caminan con sus largos vestidos, de aquí para allá, de allá para acá: nunca se asientan, nunca están satisfechos...". (Lobo, 1998, p. 9).

Además, se mencionan otros como: Don Quijote de la Mancha, el Arcipreste de Hita, pasajes de La Biblia como el de Sodoma y Gomorra; y tal vez otro de los más importantes es el Génesis bíblico: Pedro construye un paraíso terrenal en Talamanca junto a la Muda, Gerónima y los muleques; pero como Adán, será expulsado y condenado a volver a la "civilización" que arrasó el paraíso de los indígenas.

En Réquiem en Castilla del Oro los principales intertextos son los documentos de la conquista, pero también aparecen otros como: Las coplas por la muerte del padre de Jorge Manrique, Don Quijote de la Mancha y la mitología griega, los cuales, refuerzan esa visión de la cultura eurocéntrica.

\footnotetext{
"Más valiente, gallardo y fornido que Fierabrás, más terrible que jayán o Balán, más rabioso que Trasilcón; sesenta veces siete más alto que el mástil de la tierra que es Anteo, y siete veces más alto que Ticio y Tifeo, Argofeo y Mandroco juntos." (Valle-Castillo, 1999, p. 43).
}

Pedrarias, al ser comparado con estos personajes, se eleva a un nivel épico, ya no es solo el conquistador, es el caballero, el paladín de la justicia y a la vez, se convierte en el gigante, ese ser sobrenatural que trasciende los límites de la humanidad.

Pero también aparecen como intertextos el Popol Vuh y poesías en lengua Náhuatl, que representan la voz de los "otros", de los "vencidos", como lo afirma Isolda Rodríguez (2005). Estas voces silenciadas adquieren un espacio para manifestarse en un mar de lenguaje castellano, que es tan extraño y distante para ellos, como el conquistador que ahora se impone.

\footnotetext{
"nosotros cantamos: Can calagui tunal, notecu notecu,/ nexcucua, nexcucua noyolu, noyolu./ Miqui anem Tunal Tunal tit./ Mesnegui, ne nimesnegui, Tunal tit, Tunal tit,/ Tunal ma xu, ma xu tit./ Yanqui ya tunal./ Noyulo chuga..." (ValleCastillo, 1999, p. 58).
}

También se presentan anacronismos que juegan con la historia y traicionan a la Historia. Este recurso es brillantemente utilizado ya que genera un juego lingüístico que llena de momentos de humor los textos, sin desvanecer el tono histórico de las obras. 
En el caso particular de Asalto al paraíso, los anacronismos se muestran mayormente en los giros del lenguaje, pues en boca de los personajes aparecen frases de la jerga popular del siglo $X X$, estando ambientada la novela en el siglo XVIII. Paradójicamente, estos giros no desarticulan ese discurso histórico, sino que producen una cercanía con el lector y se convierten en puentes entre el pasado y el presente. Como por ejemplo:

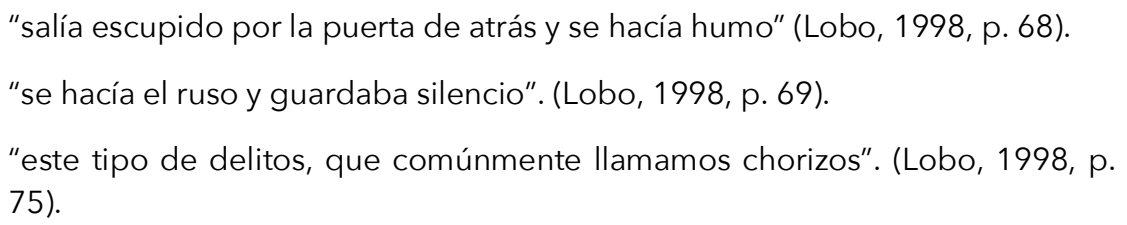

Aunque también aparecen anacronismos en el texto histórico, pues Águeda lee a Spinoza en la Costa Rica colonial. Cabe resaltar que para la quinta edición de esta novela (versión utilizada en el presente análisis) se agregó al texto una serie de imágenes pertenecientes al Álbum de Figueroa. Este detalle es interesante porque estas son completamente anacrónicas, sin embargo son usadas como una estrategia de verosimilitud.

Mientras que en Réquiem en Castilla del Oro, los anacronismos son una constante en todo el texto, desde la misma generación en el autorpersonaje, Julio Valle-Castillo, escribano real, y también ficticio. En la novela el pasado y el presente se yuxtaponen y crean interesantes juegos entre la ficción y la realidad de la $(H)$ istoria. Estos anacronismos juegan con el pasado y el futuro al mezclarlos en un mismo espacio para mostrar la continuidad de la historia que desencadena el abuso del poder y que desemboca en la violencia y el dolor. Inclusive, las víctimas de Pedrarias desfilan en el cortejo fúnebre del tirano.

"Los degollados y aperreados, las mujeres ciegas y los viejos tuertos por el polvazal de los difuntos y las abuelas arrebujadas en sus rebozos, que yacían aterradas, soterradas, semienterradas, muertos o como muertos." (ValleCastillo, 1999, p. 168).

También desfilan junto al tirano los brazos del poder y la represión que él ha instaurado en esa tierra, y trascienden a Latinoamérica, que será su herencia y perpetua presencia.

"Durante el recorrido las escuadrillas de aviones de la FUERZA AÉREA DE NICARAGUA (FAN) surcarán el espacio en forma de cruz y harán demostraciones acrobáticas y bombardearán el desfile con claveles y gardenias, enviadas especialmente por el generalísimo Rafael Leónidas Trujillo Molina". (Valle-Castillo, 1999, p. 157). 
Y no pueden faltar la parodia y la ironía que dan un tono carnavalesco, especialmente en Réquiem en Castilla del Oro, para desmitificar esa sacralidad de la Historia, de la escritura que instaura un pasado que construye la identidad.

En Asalto al paraíso, por medio de la constante crítica y denuncia de los abusos del poder. Se parodian ciertas imágenes fundadoras de los discursos oficiales que dan vida a nuestra identidad. Entre ellas se encuentran la figura de Cristo y la de San Juan Bautista, parodiadas en Fray Pablo de Rebullida, pues se le construye como un Cristo y a la vez se ironiza mediante el uso de un discurso que revela un fanatismo religioso. En él se contradice la labor evangelizadora de los religiosos.

"Rebullida, el Bautista, supo que el momento secretamente esperado de su martirio había llegado. Corría la Iglesia de paja, se arrodilló frente al altar bajo la imagencilla de San Bartolomé, abrió los brazos y alcanzó a decir "gracias, mi Dios, siervo tuyo soy, hágase tu voluntad," antes de que lo ultimara un potente macanazo" (Lobo, 1998, pp. 215-216).

"- decía el primero-. Rebullida es un cobarde porque sólo cree en el poder de convicción de las armas" (Lobo, 1998, p. 38).

Lo mismo sucede con San Francisco de Asís, que es "encarnado" por Juan de las Alas, ya que se encuentra con la naturaleza, con el paraíso, y se aleja de la oficialidad. Este paraíso lo marca y lo convierte en mártir, herido al encontrar la luz del contacto, loco para el discurso oficial, por lo cual, es ironizado también.

\footnotetext{
"Entramos a la celda y allí estaba el monje, con el sayo tirado lejos, los brazos abiertos en cruz, flotando a una cuarta del suelo, completamente arrobado, suspendido en el aire; en el centro de su pecho, la famosa herida, redonda como acabada de hacer, fresca la sangre del agujerito, colorada y saludable. El pelo antes sucio y desaliñado, le bajaba hasta los hombros brillando como el oro" (Lobo, 1998, p. 316).
}

También se parodia la Historia Oficial en la voz de Pedro, al subvertir episodios del descubrimiento, si bien Rodrigo de Triana gritó: -iTierra!, al encontrar el nuevo continente, Pedro grita -jagua!, buscando la salida de esa selva que lo asfixia y está a punto de devorarlo.

Réquiem en Castilla del Oro parodia el poder a partir del uso de ironías que evidencian la crueldad de ese poder. Su trama se basa en la liturgia católica, pero no en cualquier misa, sino en un réquiem. Una misa de muertos, que debe anunciar el fin de una vida, pero en este caso, irónicamente, la perpetúa, como lo afirma Manuel Alvarado (2000), son muertos que caminan hacia la vida y no a la muerte. El tono solemne de 
esta celebración se desvanece con la imagen satirizada del dictador Pedrarias, quien está en un supuesto proceso de muerte que no concluye. Aquí el discurso del poder, representado por el discurso religioso, el discurso inapelable de Dios, se hiperboliza y asfixia los otros discursos que buscan liberarse.

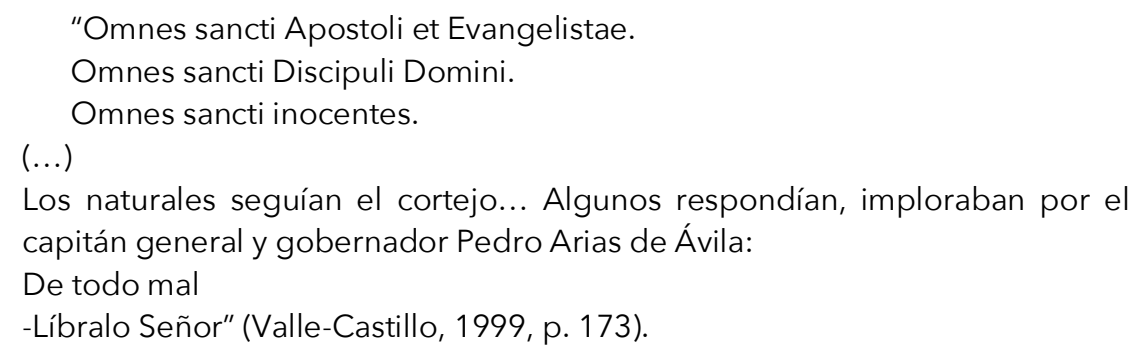

También los conquistadores y los nobles son satirizados y comparados con animales, pues son los poderosos quienes se comportan como animales salvajes que infunden terror y destruyen todo a su paso.

\begin{abstract}
"Un lebrel negro, de cuello blanco como gorguera, con una estampa o porte archiducal, hizo alardes de elasticidad, porque no había acabado de desgarrar el vientre de uno de los indio cuando arrancaba correas de la espalda de otro" (Valle-Castillo, 1999, p. 124).
\end{abstract}

\title{
Memoria, tiempo y espacio: búsqueda del pasado, el presente y el futuro
}

En ambas novelas mezclan los espacios y tiempos, ya que no se limitan a una ubicación geográfica única ni a un tiempo específico. Así, lo no simultáneo se vuelve simultáneo, se amalgama puesto que un gran número de elementos tales como etnias, lenguajes, poderes y costumbres se integran y se distancian a la vez.

Pedro Albarán se desplaza de España hacia América hasta llegar a Costa Rica, pero no solo se queda en Cartago sino que se desplaza hacia Matina y Talamanca. Al moverse de un lugar se encuentra con mundos diferentes: el de los indígenas y el de los negros. Y en su encuentro con la Muda descubre la existencia de otro tiempo, un tiempo perdido, el tiempo primigenio de la vida indígena antes de la llegada de los españoles, a tal punto, que él mismo se autoexilia en ese paraíso precolombino.

"Era una mirada vacua, perdida en el tiempo ilimitado de su sueño, y convergía hacia un vértice localizado en la nada, ... La mirada de la muda durmiente hacia el nadir lo fascinó, ... fuente subterránea de donde emergían sus sueños corporeizados, extrañas criaturas desconocidas, misteriosos seres arcaicos, animales mitológicos y hombres y mujeres desnudos e inocentes..." (Lobo, 1998, p. 131). 
En Réquiem en Castilla del Oro, Pedrarias une los dos continentes: Europa y América, pues él viene de España a perpetuar esa visión de mundo aquí en América, y se encarga de esparcir ese 'modus vivendi' en su periplo por Centroamérica, ya que se desplaza de Panamá a Nicaragua. Y también atraviesa diferentes temporalidades desde el pasado de la conquista, pasando por el pasado dictatorial de Nicaragua hasta pervivir en un monitor de la actualidad tecnológica.

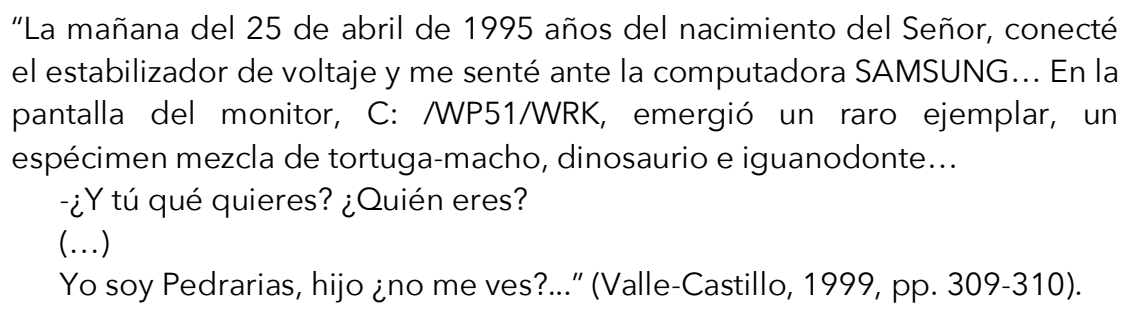

Las miradas se desplazan desde el pasado escrito, recordado e imaginado, pasan por un presente que se dice y también se escribe, y se quedan clavadas en "el nadir", como la mirada de la muda soñando el futuro.

\section{Consideraciones finales}

Tanto en Asalto al paraíso como en Réquiem en Castilla del Oro no solo nos encontramos frente a una Historia Oficial y una no oficial, sino que nos perdemos en un viaje que genera la escritura hacia la memoria, una memoria olvidada. Ya que hablar de historia, en nuestro contexto, es hablar de otredad y esto implica una ficcionalización, porque se debe tomar posición frente a lo extraño. Por esta razón, ambos textos son dialógicos, pues en el momento en que soy afectado por esa otredad, se genera la polifonía de la historia y la memoria.

Con estos textos se nos plantea que el pasado es colectivo ya que todos tenemos derecho a la memoria que la oficialidad borra, al arrancar las páginas que atentan contra el poder. Con solo la imagen de PabrúPresbere que es anulada hasta el punto de que su nombre se castellaniza: Pablo, se evidencia la fragmentación de la Historia. Ya no solo los procesos escriturales-históricos producen memoria, ahora la oralidad también recobra el recuerdo. Y más importante aún, que es el recuerdo de los marginados para recuperar su identidad.

El poder ha buscado soterrar las voces de esos otros marginados, anularlos, para escuchar el réquiem que crece para nuestra convulsa 
Centroamérica, pero las mínimas voces de esos otros siguen colándose por rincones de la Historia, en los recuerdos, en la ficción, para no ser olvidadas. La voz de esos otros nos grita con tenues ecos de recuerdo que están allí, que siempre lo han estado, aunque la oficialidad los amordace para borrar el susurro de sus cantos olvidados y escriba la Historia con el fin de borrar sus nombres de nuestras memorias (historias). 


\section{BIBLIOGRAFÍA}

Alvarado Murillo, M. (2000). "Réquiem en Castilla del oro, canto exequial a la sucesión perpetua del poder", en: Academia Nicaragüense de la Lengua: Managua. Época 2. Número 22.

Chaverri Fonseca, A. (1997). Asalto al paraíso: Una transmetáfora que rescribe la historia. Tesis para optar por el grado de Magíster Litterarum en Literatura Latinoamericana de la Universidad de Costa Rica. Sistema de Estudios de Posgrado. Comisión del Posgrado en Literatura Latinoamericana.

González Vásquez, F. (2002). "Tatiana Lobo: Artífice de la palabra", en: Comunicación, noviembre, año/vol. 12, edición especial. Instituto Tecnológico de Costa Rica. Cartago, Costa Rica. Recuperado de: http://revistas.tec.ac.cr/index.php/comunicacion/article/view/1248/1152 Consultado: 10 de octubre, 2016.

Grinberg Pla, V. (2002). "La novela histórica como un espacio alternativo para la (de)construcción de identidades: sobre El Año del Laberinto de Tatiana Lobo". En Comunicación, noviembre año/vol. 12, edición especial. Instituto Tecnológico de Costa Rica. Cartago, Costa Rica. Recuperado de: http://revistas.tec.ac.cr/index.php/comunicacion/article/view/1237

Consultado: 15 de octubre de 2016.

Grinberg Pla, V. (2001). "La novela histórica de finales del siglo XX y las nuevas corrientes historiográficas", en: Istmo, Número 2. Recuperado de: http://colaborations.denison.edu/istmo Consultado: 23 de octubre de 2016.

Leyva, H. M. (2005). "Narrativa centroamericana post noventa. Una exploración preliminar", en: Istmo, Número 11. Recuperado de: http://colaborations.denison.edu/istmo Consultado: 27 de octubre de 2016.

Lobo, Tatiana. (1998). Asalto al paraíso. Editorial de la Universidad de Costa Rica. San José. 
Mackenbach, W. (2000). "La nueva novela histórica en Nicaragua y Centroamérica", en Istmo, Número 1. Recuperado de: http://colaborations.denison.edu/istmo Consultado: 27 de octubre de 2016.

Mackenbach, W. (2004). "Después de los pos-ismos: ¿desde qué categorías pensamos las literaturas centroamericanas contemporáneas?", en Istmo, Número $8 . \quad$ Recuperado de: http://colaborations.denison.edu/istmo Consultado: 29 de octubre de 2016.

Midence, C. "Lo Barroco en Réquiem en Castilla del oro", en Nuevo Amanecer cultural- END. El nuevo diario. Sábado 12 de junio de 1999. Managua, Nicaragua. Recuperado de: http://archivo.elnuevodiario.com.ni/cultural/40851-barroco-requiemcastilla-oro/ Consultado: 30 de octubre de 2016.

Menton, S. (1993). La nueva novela histórica de América Latina, 1979-1992. México, D.F. Fondo de Cultura Económica.

Pons, M. C. (1996). Memorias del olvido. Del Paso, García Márquez, Saer y la novela histórica de fines del siglo XX. México, D.F. Siglo XXI.

Rodríguez Rosales, I. (1999). Una década en la narrativa nicaragüense y otros ensayos. Managua: Centro Nicaragüense de escritores.

Rodríguez Rosales, I. (2005). "Réquiem en Castilla del oro o la ficción de la historia", en: Istmo, Número 10. Recuperado de: http://colaborations.denison.edu/istmo Consultado: 2 de noviembre de 2016.

Shea, M. (2002). "Asalto al paraíso: Tatiana Lobo asalta la Historia Oficial", en Comunicación, noviembre, año/vol. 12, edición especial. Instituto tecnológico de Costa Rica, Cartago, Costa Rica. Recuperado de: http://revistas.tec.ac.cr/index.php/comunicacion/article/view/1238

Consultado: 10 de noviembre de 2016.

Valle-Castillo, J. (1999). Réquiem en Castilla del oro. Managua: Centro Nacional de Escritores. ANR/NORAD/CNE. 
Vargas, M. (1997). "Asalto al paraíso Historia ficcional o ficción histórica". En: Comunicación, Agosto, Vol. 9, № 2 Año 18: pp. 72-79. 